\title{
Penggunaan Alih Kode Instruktur dalam Proses Belajar Mengajar Bahasa Inggris di ELC Education Manado
}

\author{
Mardyane Mandang \\ Leika M. V. Kalangi \\ Golda Tulung
}

\begin{abstract}
This study focussing on the use of code switching produced by instructors in English teaching and learning process based on Sosiolinguistics and language teaching point of view. This research uses qualitative method and records the process of teaching English and interviews the instructors and students as a technique of this research to find the importance of code switching. The data were transcripted and analyzed use the concepts of Wardhaugh and Suwito about types of code switching and functions of code switching use the concept of Margana. The research shows that there are 4 types of code switching intern, extern, metaphorical dan situasional code switching. Extern code switching are code switching from English to Indonesian (i.e. do you know what day is tomorrow? Besok hari apa?) and English to Manado Malay (i.e. you know what I mean? Mangarti nda?). Intern code switching is code switching from Manado Malay to Indonesian (i.e. besok hari libur jadi nda ada les. Lesnya nanti minggu depan). Metaphorical code switching is a code switching without any changing topic. Situasional code switching is a code switching with changing topic. Also, there are 7 types of code switching, they are repetition, clarification, exploration, explanation, giving assignment, checking students' understanding and giving warning/suggestion. It can be concluded that there are 4 types of code switching produced by instructors in English teaching and learning process. They are extern, intern, metaphorical and situasional code switching. Besides, there are 7 functions of code switching. They are repetition, clarification, exploration, explanation, giving assignment, checking students' understanding and giving warning/suggestion.
\end{abstract}

Key words : Code switching, Instructors utterences, English teaching and learning process

\section{Pendahuluan}

Bahasa memegang peran penting dalam berkomunikasi. Bahasa di samping sebagai alat komunikasi, juga digunakan sebagai alat untuk menyampaikan suatu ide, pikiran, hasrat dan keinginan kepada orang lain. Komunikasi tidak berjalan lancar tanpa bahasa.

Masyarakat saat ini dituntut untuk mampu menggunakan bahasa Inggris dalam kehidupan berinteraksi dan berkomunikasi. Bahasa Inggris sebagai bahasa internasional 
diwajibkan untuk diajarkan di sekolah-sekolah dan tempat kursus. Bahasa Inggris sudah menjadi keharusan untuk dipelajari. Hal inilah yang membuat banyak orang khususnya murid menggunakan sarana tempat kursus sebagai tempat mereka mempelajari bahasa Inggris lebih banyak.

Tempat kursus adalah tempat belajar informal yang memfasilitasi murid untuk mendapatkan ilmu pengetahuan atau menambah pengetahuan selain di sekolah tempat mereka belajar.

ELC Education sebagai salah satu tempat kursus bahasa Inggris yang telah dikenal oleh masyarakat di Manado juga menjadi pilihan para murid yang ingin memperdalam kemampuan bahasa Inggris mereka. Murid-murid sekarang ini menyadari pentingnya bahasa Inggris untuk kehidupan mereka nanti. Banyak murid yang mengikuti kursus di tempat tersebut dengan banyak tujuan, di samping meningkatkan kemampuan berbahasa Inggris mereka, mereka juga mengikuti kelas bahasa Inggris tersebut untuk keperluan melanjutkan pendidikan baik dalam maupun luar negeri, syarat lulus pendidikan S2 dan S3 dan juga syarat untuk melamar pekerjaan.

Pengguna bahasa yang baru mempelajari bahasa ataupun pengguna bahasa yang ingin menambah pengetahuan baru tentu menemukan kesulitan-kesulitan. Kesulitan juga bukan hanya dialami oleh pelajar tetapi juga dialami pengajar. Instruktur harus membantu murid sehingga mereka memahami apa yang diajarkan. Murid di dalam kelas memiliki tingkat kemampuan yang berbeda. Ada murid yang cepat memahami dan ada juga yang agak sulit untuk memahami. Perlu adanya pengalihan bahasa dari bahasa asing ke bahasa Indonesia bahkan dapat juga dialihkan ke bahasa ibu mereka. Pengalihan bahasa ini disebut alih kode. Alih kode sangat membantu instruktur dalam mengajar di kelas sehingga maksud yang disampaikan dapat diterima dengan baik oleh murid.

Hanifatul (2009) menyatakan dalam proses belajar-mengajar alih kode sering dilakukan karena adanya kendala-kendala yang dialami siswa. Kendala-kendala tersebut seperti kendala kemampuan siswa dalam penguasaan bahasa Inggris beragam yakni kendala dalam bercakap-cakap dalam bahasa Inggris, minimnya penguasaan perbendaharaan kata pada siswa, kurangnya rasa percaya diri pada siswa, kurangnya motivasi siswa dalam mempelajari bahasa Inggris, metode mengajar yang kurang tepat, materi ajar yang tidak sesuai dengan kebutuhan, dan lingkungan yang kurang mendukung siswa dalam pembelajaran bahasa Inggris. Menurutnya, salah satu solusi terhadap kendalakendala tersebut yaitu dengan melakukan alih kode.

Penggunaan alih kode dalam proses belajar-mengajar bukan hanya dilakukan oleh murid tetapi juga dapat dilakukan oleh guru. Junyati (2012) menyatakan bahwa alih kode terjadi karena guru dengan sadar menggunakannya. Dia menambahkan bahwa guru nonbahasa asing memiliki kecenderungan untuk menggunakan alih kode pada proses belajar mengajar karena merupakan persyaratan di kelas dwibahasa, kemudahan ungkapan, pengulangan ide utama dan sosialisasi istilah-istilah asing yang kurang diketahui. Dia juga menyarankan alih kode untuk digunakan demi mencapai kesuksesan proses belajarmengajar.

Instruktur bahasa asing harus mempunyai pengetahuan mengenai linguistik untuk mengatasi kesulitan dalam mengajar bahasa. Martinet (1987:19) menyatakan bahwa linguistik merupakan telaah ilmiah mengenai bahasa manusia. Linguistik akan memberi pemahaman pada pengguna bahasa tentang hakikat dan seluk beluk bahasa sebagai alat komunikasi untuk berinteraksi dengan masyarakat.

Ilmu yang mempelajari bagaimana bahasa digunakan dalam kehidupan suatu masyarakat yaitu Sosiolinguistik. Fishman (dalam Chaer dan Agustina, 2010:3) 
menyatakan bahwa sosiolinguistik merupakan kajian tentang ciri khas variasi bahasa, fungsi variasi bahasa, dan pemakai bahasa karena ketiga unsur ini selalu berinteraksi, berubah dan saling mengubah satu sama lain dalam masyarakat tutur.

Konvensi diperlukan karena adanya banyak variasi, fungsi dan pemakai bahasa. Maksudnya telah ada kesepakatan terhadap penggunaan kata-kata yang digunakan dengan kelompok pemakainya. Konvensi ini juga dipelajari dalam sosiolinguistik. Tanpa adanya konvensi akan terjadi kebingungan dan ketidakjelasan dalam proses komunikasi suatu masyarakat.

Menurut Criper dan Widdowson (dalam Chaer dan Agustina, 2010:4), sosiolinguistik adalah kajian bahasa dalam penggunaannya dengan tujuan untuk meneliti konvensi pemakaian bahasa berhubungan dengan aspek-aspek lain dari tingkah laku sosial.

Salah satu yang dibahas dalam sosiolinguistik yaitu alih kode. Pemakai bahasa harus dapat menempatkan diri dalam segala situasi dan menggunakan bahasa yang tepat berdasarkan situasi tersebut dalam berkomunikasi. Menurut Menurut Wardhaugh (1986) alih kode dibagi dalam dua jenis yaitu alih kode metaforis dan situasional, sedangkan menurut Suwito (dalam Chaer dan Agustina, 2010:114) alih kode dibagi dalam dua jenis yaitu alih kode eksteren dan interen. Peristiwa alih kode dalam proses belajar-mengajar ini terjadi karena pihak yang berinteraksi mengenal lebih dari satu bahasa (Margana, 2012:3). Sebagai contoh dalam proses belajar-mengajar di tempat kursus yang ada di Manado, alih kode terjadi karena pihak yang berinteraksi dalam hal ini instruktur dan murid mengenal lebih dari satu bahasa yaitu bahasa Melayu Manado (BMM), bahasa Indonesia (BIndo) dan bahasa Inggris (BIng).

ELC Education sebagai salah satu tempat kursus bahasa Inggris dalam proses belajar-mengajar juga tidak lepas dari penggunaan alih kode. Instruktur menggunakan alih kode dengan tujuan untuk membantu siswa memahami apa yang dijelaskan.

Alih kode lebih banyak digunakan pada kelas anak-anak karena pada kelas ini masih banyak hal yang sangat perlu diketahui anak-anak tentang bahasa Inggris. Perbedaan tingkatan kelas juga mempengaruhi penggunaan alih kode. Jika pada kelas anak-anak sampai kelas SMP, instruktur banyak melakukan alih kode, maka pada kelas SMA, kelas dewasa, TOEFL, dan IELTS, instruktur mengurangi pengunaan alih kode.

Pengurangan alih kode tersebut dikarenakan pada tingkatan ini murid sudah lebih banyak memiliki kemampuan bahasa Inggris dari segi banyaknya kosakata, tata bahasa, kemampuan membaca, menulis dan mendengar. Pada tingkat ini juga murid sudah lebih banyak memahami pelajaran yang diberikan meskipun instruktur lebih banyak menggunakan bahasa Inggris dalam penjelasannya.

Berdasarkan kendala-kendala murid dalam mempelajari bahasa Inggris, maka dilakukan penelitian tentang jenis, fungsi alih kode dalam proses belajar mengajar bahasa Inggris di kelas anak-anak.

\section{Kerangka Teoretis}

Berikut ini akan dijelaskan kaitan sosiolinguistik dan proses belajar mengajar bahasa, bilingualisme, proses belajar mengajar bahasa Inggris pada anak-anak dengan alih kode instruktur khususnya jenis dan fungsi alih kode tersebut dalam proses belajar mengajar bahasa Inggris.

\section{Sosiolinguistik dan Proses Pembelajaran bahasa}


Alih kode yang menjadi salah satu pembahasan ilmu dalam sosiolinguistik memiliki keterkaitan dengan proses pembelajaran bahasa khususnya bahasa Inggris. Chaer dan Agustina (2010:2) menyatakan bahwa sosiolinguistik merupakan ilmu antardisiplin yaitu antara sosiologi dan linguistik. Sosiologi mempelajari bagaimana masyarakat terjadi, berlangsung dan tetap ada; sedangkan linguistik mempelajari bahasa.

Sosiolinguistik merupakan salah satu ilmu linguistik yang sangat penting dipelajari karena sosiolinguistik merupakan ilmu yang mempelajari bagaimana suatu bahasa digunakan dalam kehidupan suatu masyarakat. Kaitannya dengan alih kode instruktur dalam proses belajar mengajar bahasa Inggris, bahasa yang muncul saat alih kode sangat bervariasi karena pemakaian bahasa di tempat alih kode itu berlangsung juga bervariasi.

Proses alih kode terjadi karena adanya penutur yaitu instruktur, pendengar yaitu murid-murid yang saling berkomunikasi dalam kelas, lingkungan tempat mereka bertemu, adanya variasi dialek yang muncul karena baik instruktur maupun murid berasal dari latar belakang sosial yang berbeda sehingga akan berpengaruh pada ujaran mereka. Identitas sosial penutur (instruktur) dan lingkungan sosial penutur (instruktur) maupun lawan tutur (murid) berpengaruh pada pemilihan kode.

Pernyataan ini juga didukung oleh Fishman (dalam Chaer dan Agustina, 2010:7) yang merumuskan bahwa yang dipersoalkan dalam sosiolinguistik yaitu "who speak, what language, to whom, when and to what end". Penutur dalam berinteraksi atau berkomunikasi dengan lawan tutur harus menggunakan bahasa yang dapat dipahami oleh kedua orang atau kelompok tersebut. Tujuan dari tuturan juga harus dituturkan dengan jelas sesuai dengan kondisi siapa yang diajak bicara. Berkaitan dengan alih kode yang dilakukan instruktur dalam proses belajar mengajar bahasa Inggris, instruktur harus menggunakan bahasa yang dapat dipahami oleh murid. Materi pembelajaran yang diberikan instruktur harus jelas sehingga murid dapat memahami materi pembelajaran tersebut. Cara pengajaran juga harus disesuaikan dengan kondisi kemampuan murid. Ada murid yang cepat memahami dan ada yang lambat memahami. Oleh karena itu, cara pengajarannya harus disesuaikan agar proses pembelajaran dapat berlangsung dengan maksimal.

Proses pembelajaran bahasa tidak akan sukses tanpa adanya ilmu-ilmu lain yang saling menunjang. Ilmu-ilmu yang berkontribusi pada pembelajaran bahasa yaitu linguistik, sosiolinguistik, psikolinguistik, pedagogik, psikologi, sosiologi dan antropologi. Dalam analisis alih kode, alih kode itu sendiri termasuk dalam ilmu sosiolinguistik karena mempelajari penggunaan bahasa yang tepat dalam proses berinteraksi dengan masyarakat pemakai bahasa.

Fishman (1972) mengemukakan mengenai bahasa secara sosiolinguistis yang bukan hanya berupa struktur kata-kata, tetapi juga bahasa berfungsi sebagai alat interaksi sosial yang mencerminkan konstruks masyarakat pemakai bahasa tersebut.

Berkaitan dengan penggunaan alih kode instruktur dalam proses belajar mengajar bahasa, bahasa yang dituturkan instruktur bukan hanya sekedar bertutur saja tetapi berfungsi sebagai alat interaksi yang membantu murid mendapatkan ilmu yang lebih banyak tetapi juga melalui tuturan instruktur tersebut murid dapat memahami maksud dan tujuan pembelajaran. Melalui pengalihan kode (bahasa) kesulitan-kesulitan murid dapat teratasi. Pengalihan kode yang dipilih instruktur mencerminkan identitas instruktur tersebut seperti instruktur yang melakukan pengalihan kode ke bahasa Melayu Manado menceriminkan instruktur tersebut berasal dari Manado atau telah lama tinggal sehingga telah mengetahui bahasa tersebut. 
Peran sosiolingustik dalam pembelajaran bahasa sangat penting. Sekarang ini, khususnya dalam pembelajaran bahasa asing, banyak pembelajar yang telah mempelajari bahasa asing tersebut dalam waktu yang lama, namun mereka tidak dapat berkomunikasi menggunakan bahasa yang tepat karena yang diajarkan hanyalah tata bahasanya saja tetapi tidak memperhatikan aspek sosial bahasa. Pernyataan ini didukung oleh Holmes (1992) yang menekankan bahwa pembelajar perlu dibekali dengan pengetahuan lintas budaya.

Berdasarkan teori sosiolinguistik yang menyatakan bahwa sosiolinguistik merupakan ilmu yang mempelajari bahasa yang digunakan dalam interaksi kehidupan masyarakat, bahasa Inggris yang digunakan dalam interaksi antara murid dan instruktur dalam proses belajar mengajar sulit dipahami. Murid mengalami kesulitan sehingga perlu dilakukan alih kode untuk mengatasinya. Murid kesulitan untuk memahami apa yang disampaikan oleh instruktur ketika instruktur tersebut menggunakan bahasa Inggris. Adanya kesulitan tersebut membuat instruktur yang awalnya menjelaskan dan berbicara dalam bahasa Inggris melakukan alih kode ke bahasa yang dipahami murid tersebut.

Pengalihan bahasa yang dilakukan instruktur tersebut yaitu alih kode eksteren. Tidak tertutup kemungkinan instrukturpun yang awalnya menjelaskan dalam bahasa yang dipahami murid melakukan alih kode ke dalam bahasa Inggris dengan tujuan agar murid dapat mempraktekkan apa yang diajarkan dalam bahasa Inggris. Untuk mencapai tujuan tersebut, terdapat beberapa fungsi alih kode yang dapat digunakan sehingga proses belajar mengajar dapat berlangsung dengan baik dan meminimalisir kesulitan murid.

Murid yang mengalami kesulitan dalam belajar bahasa Inggris biasanya dipengaruhi oleh lingkungan sosialnya seperti lingkungan sekolah, pergaulan dan keluarga. Murid mengalami kesulitan dalam belajar karena tidak adanya bantuan dari orang tua yang membantu murid tersebut belajar di rumah sehingga murid tidak mempunyai lawan bicara untuk mempraktekan kemampuan bahasa Inggrisnya.

Selain itu, lingkungan sekolah dan pergaulan juga mempengaruhi. Di sekolah murid tidak dapat mempelajari bahasa Inggris lebih spesifik karena banyaknya murid dalam kelas sehingga kemampuan mereka kurang meningkat. Lingkungan pergaulan yang tidak mendorong murid tersebut untuk mempraktekkan kemampuan berbahasa Inggrisnya membuat murid malu membuat kesalahan dan takut mempraktekan kemampuannya.

\section{Bilingualisme}

Penggunaan alih kode dalam proses belajar mengajar bahasa dengan bilingualisme memiliki keterkaitan. Suatu masyarakat dalam berinteraksi pasti membutuhkan bahasa. Bahasa yang digunakan sangat bervariasi. Pengguna bahasa yang menggunakan lebih dari satu bahasa disebut bilingual. Brown (2007) menyatakan kebanyakan bilingual melakukan tindakan alih kode yaitu tindakan memasukkan kata, frase, atau yang lebih panjang lagi dari sebuah bahasa ke bahasa lain terutama ketika berkomunikasi dengan sesama bilingual. Penggunaan bilingualisme sangat diperlukan dalam proses belajar mengajar.

Menurut Basel dan Hidayat (2011:30,) penggunaan dua bahasa bukan semata-mata untuk pencapaian akademik tapi jauh lebih penting untuk integrasi bangsa. Penggunaan monolingual berakibat pada murid sulit memahami konsep akademik dan berujung pada prestasi yang buruk dan kepribadian murid yang menurun.

Weinreich (1968:5) menyatakan bahwa bilingualisme merujuk pada penggunaan dua bahasa secara bergantian. Pengguanaan bahasa secara bergantian ini bisa berupa penggunaan bahasa asing ke bahasa lokal atau sebaliknya. Penggunaan lebih dari satu bahasa ini digunakan dengan melihat situasi yang ada. Pengguanaan bilingualisme ini harus memperhatikan kemampuan pengguna bahasa. Dalam kaitannya dengan penggunaan 
alih kode dalam proses belajar mengajar bahasa Inggris, penggunaan bilingualisme harus memperhatikan kemampuan murid. Jika murid tidak memahami materi pembelajaran dengan bahasa yang digunakan instruktur maka, instruktur harus memilih bahasa yang lain yang dapat digunakan instruktur dan dapat dipahami murid.

Instruktur dan murid merupakan pengguna bahasa yang menggunakan lebih dari satu bahasa. Bilingualisme dan alih kode memiliki keterkaitan. Saat melakukan alih kode, disitulah proses bilingualisme terjadi. Saat instruktur melihat murid mereka tidak memahami apa yang dituturkan maka proses bilingualisme terjadi melalui penggunaan alih kode.

Di bidang pendidikan, penggunaan bilingualisme juga dikaitkan dengan keterampilan bahasa guru (instruktur) dan murid apalagi jika keterampilan guru (instruktur) ataupun murid berada pada tingkat dasar atau pemula. Macnamara (dalam Margana 2010:9) juga menyatakan bahwa tingkat pengetahuan pemula merujuk pada penggunaan keterampilan berbahasa seperti membaca, berbicara, menulis dan menyimak. Di kelas anak-anak, murid pada kelas ini mempelajari keterampilan membaca, bicara, menulis dan menyimak. Kesulitan-kesulitan murid seperti dalam hal kosakata yang masih sedikit membuat mereka sulit membaca dan memahami arti bacaan yang ditulis dalam bahasa Inggris, kesulitan dalam berbicara juga terjadi karena kurangnya kosakata dan tata bahasa, kemampuan menulis kata-kata dalam bahasa Inggris dan kemampuan menyimak yang masih kurang karena pada kelas ini anak-anak belum memiliki konsentrasi penuh dalam memahami pelajaran. Untuk meminimalisir kesulitan-kesulitan tersebut, instruktur perlu melakukan alih kode namun harus digunakan seperlunya saja.

\section{Alih Kode}

Alih kode dapat digunakan bukan hanya dalam interaksi masyarakat sesama pengguna bahasa tetapi dapat diterapkan dalam proses belajar mengajar bahasa khususnya bahasa Inggris. Menurut Hudson (1996) "Anyone who speaks more than one language chooses between them according to circumstances". Seseorang yang menggunakan lebih dari satu bahasa menggunakan bahasa yang tepat sesuai dengan situasi yang ada. Orang tersebut memilih bahasa yang dia ketahui untuk digunakan sesuai dengan siapa yang diajak bicara, tujuan dan situasi saat orang tersebut berbicara. Dalam kaitannya dengan alih kode instruktur dalam proses belajar mengajar bahasa Inggris, instruktur harus memilih bahasa yang tepat dan sesuai untuk digunakan dalam proses alih kode sesuai dengan kondisi dan kemampuan murid, tujuan dilakukan alih kode dan ketepatan situasi dalam menggunakan alih kode. Beberapa ahli telah menjelaskan tentang alih kode. Wardhaugh (1986:104) membagi alih kode menjadi dua jenis yaitu alih jenis alih kode metaforis dan alih kode situasional. Alih kode metaforis yaitu alih kode yang terjadi jika ada pergantian topik; sedangkan alih kode situasional yaitu alih kode yang terjadi berdasarkan situasi dimana para penutur menyadari bahwa mereka berbicara dalam bahasa tertentu dalam suatu situasi dan bahasa lain dalam situasi yang lain. Alih kode ini tidak terjadi perubahan topik.

Chaer dan Agustina (2010) menyatakan bahwa alih kode dilakukan karena adanya peristiwa pergantian bahasa oleh seorang penutur dengan sadar. Ditemukan seorang instruktur menggunakan pergantian bahasa dengan sadar karena adanya tuntutan yang harus dilakukan. Instruktur melakukan alih kode dalam proses belajar mengajar bahasa Inggris karena instruktur sadar dengan melakukan alih kode kesulitan murid dalam memahami pelajaran dapat diminimalisir. Hal inilah yang menjadi tuntutan bagi seorang instruktur yang mengajar bahasa asing dalam membantu murid memahami pelajaran. 
Suwito (dalam Indrastuti, 1997:39) juga membagi alih kode menjadi dua yaitu jenis alih kode interen dan eksteren. Alih kode interen yaitu alih kode yang berlangsung antarbahasa yang digunakan dalam suatu negara yang dikuasai oleh individu atau yang digunakan oleh pengguna bahasa itu sendiri, seperti dari bahasa Indonesia ke bahasa Melayu Manado atau sebaliknya; sedangkan alih kode eksteren yaitu alih kode yang terjadi antarbahasa seperti bahasa Indonesia dengan bahasa asing, seperti pengalihan dari bahasa Indonesia ke bahasa Inggris atau sebaliknya.

Fishman (dalam Chaer dan Agustina, 2010:108) menyatakan penyebab terjadinya alih kode dilihat dari pokok persoalan sosiolinguistik seperti siapa yang berbicara, dengan bahasa apa, kepada siapa, kapan dan dengan tujuan apa. Dalam proses belajar mengajar bahasa Inggris, instruktur harus mengetahui bahasa yang tepat untuk digunakan dalam proses alih kode, tujuan dilakukannya alih kode, kemampuan murid dalam memahami pelajaran dan situasi yang tepat untuk dilakukan alih kode.

Margana (2012:16-17) menyatakan ada banyak fungsi alih kode dalam proses komunikasi di kelas yang dikategorikan dalam beberapa kategori yaitu fungsi utama alih kode untuk pembelajaran materi, pengelolaan kelas dan pemarkah wacana. Selain itu ada beberapa fungsi alih kode dalam pembelajaran materi yaitu fungsi klasifikasi, reiterasi, eksplanasi, eksplorasi, elaborasi, pengecekan pemahaman, penekanan terhadap unsurunsur kebahasaan tertentu, membuat interferensi, mengembangkan kosakata, membahas tugas peserta didik, memberi feedback dan sebagai refleksi.

Dilihat dari fungsinya dalam pengelolaan kelas, alih kode berfungsi untuk menarik perhatian murid, memberikan arahan, menandai pergantian topik, meminta bantuan murid, mengatasi ketegangan, menjaga kedisiplinan peserta didik, memberi motivasi kepada peserta didik, memberi apresiasi terhadap peserta didik, memarahi peserta didik dan memelihara hubungan interpersonal. Fungsi-fungsi tersebut dapat diterapkan dalam proses belajar mengajar bahasa Inggris di kelas anak-anak sesuai dengan situasi dan tujuan yang ingin dicapai.

\section{Proses Belajar Mengajar Bahasa Inggris Pada Anak-Anak}

Proses belajar mengajar bahasa Inggris pada anak-anak memiliki keterkaitan dengan alih kode. Belajar adalah proses untuk menemukan dan mengetahui sesuatu. Kita mendapatkan ilmu atau informasi yang belum diketahui sebelumnya jika mau belajar. Terdapat faktor-faktor yang mempengaruhi seseorang dalam mempelajari sesuatu. Faktorfaktor tersebut seperti faktor non sosial (alat tulis-menulis, buku-buku, ruangan/kelaas, cuaca, dll), faktor sosial (orang lain), faktor fisiologis dan faktor psikologis (Suryabrata, 2008).

Cara siswa dan orang dewasa mempelajari bahasa Inggris berbeda. Perbedaan ini menimbulkan masalah yang penting untuk diperhatikan. Cameron (2001:24) menyatakan karena anak usia dini berada pada masa pertumbuhan, perkembangan motorik, bahasa, sosial dan konseptualnya perlu diperhatikan. Isi pembelajaran lebih dipusatkan pada pengembangan keterampilan berbahasa, kosakata, serta penggunaan bahasa pada tingkat wacana dengan metode pembelajaran yang interaktif seperti melalui games, lagu, irama atau cerita. Kosakata sangat penting dan merupakan dasar dalam mempelajari bahasa Inggris. Tanpa adanya kemampuan dalam menguasai kosakata, murid akan kesulitan dalam berinteraksi dan mengerjakan tugas. Harley (1996) dalam penelitiannya menunjukkan bahwa tanpa adanya pengetahuan yang mencukupi akan kosakata yang relevan, siswa mengalami kesulitan membuat tugas kosakata. 
Proses pembelajaran bahasa Inggris pada anak-anak diberikan secara bertahap karena kemampuan anak dalam memahami pelajaran tidak sama dengan orang dewasa. Hal penting yang perlu diperhatikan yaitu metode pembelajaran. Proses belajar mengajar akan berhasil jika metode pembelajaran sesuai dengan tingkat kemampuan seseorang. Matondang (2005) menyatakan bahwa mengingat Bahasa Inggris merupakan bahasa asing di Indonesia, maka proses pembelajarannya harus dilakukan secara bertahap. Pemilihan materi yang sesuai dengan usia anak dan situasi belajar yang menyenangkan haruslah menjadi perhatian utama dalam berhasilnya suatu proses pembelajaran.

Proses pembelajaran bahasa Inggris pada anak akan berhasil jika adanya guru yang mengajar, fasilitas yang memadai dan metode pembelajaran yang tepat dan efektif. Matondang (2005) juga menambahkan, keberhasilan proses belajar mengajar bahas Inggris pada anak usia dini dipengaruhi oleh banyak factor yaitu: guru yang berkualitas, sumber dan fasilitas pembelajaran yang memadai dan kurikulum yang baik dan sederhana. Faktorfaktor tersebut saling menunjang dan tidak dapat dipisahkan.

Peneltian ini membahas jenis dan fungsi alih kode instruktur di kelas anak-anak karena pada kelas ini, anak-anak masih mulai belajar mengenal bahasa. Kurangnya penguasaan kosakata merupakan salah satu penyebab guru melakukan alih kode. Jenisjenis alih kode diteliti menggunakan konsep Suwito (1985) dan Wardhaugh (1986) dan fungsi-fungsi alih kode diteliti menggunakan konsep Margana (2012).

\section{METODE}

Teknik pengumpulan data sangat penting dalam penelitian. Tujuan utama dari teknik pengumpulan data yaitu untuk mendapatkan data.

Pada penelitian kualitatif, pengumpulan data dapat dilakukan pada kondisi alamiah, sumber data primer, observasi dan wawancara (Sugiyono, 2010:225).

Pengumpulan data yang diambil berupa rekaman proses belajar mengajar. Teknik perekaman untuk mencari apakah ada alih kode yang dilakukan. Berdasarkan hasil rekaman, akan diketahui jenis-jenis alih kode yang terjadi. Dalam teknik rekam ini, setiap instruktur direkam tuturannya dalam proses belajar mengajar sebanyak satu kali rekaman pada 5 instruktur yang mengajar di kelas anak-anak.

Dalam penelitian ini penulis juga menggunakan metode wawancara. Wawancara dilakukan kepada 5 orang instruktur dan 4 orang murid untuk memperoleh informasi mengenai jenis-jenis alih kode yang digunakan instruktur, pentingnya alih kode dalam proses belajar mengajar bahasa Inggris, untuk menggali fungsi-fungsi alih kode yang dilakukan instruktur dan mengetahui manfaat alih kode dalam proses belajar mengajar.

\section{PEMBAHASAN}

Hasil penelitian pada instruktur yang mengajar di kelas anak-anak di ELC Education Manado, digambarkan sesuai dengan tujuan penelitian yaitu untuk mengidentifikasi dan mendeskripsikan jenis-jenis alih kode dan menjelaskan fungsi-fungsi alih kode. Jenis-jenis dan fungsi-fungsi alih kode yang digunakan insruktur dapat dilihat pada bagian analisis berikut.

\section{Jenis Alih Kode}

Penelitian pada instruktur yang mengajar di kelas anak-anak di ELC Education Manado, digambarkan sesuai dengan tujuan penelitian yaitu untuk mengidentifikasi dan 
mendeskripsikan jenis-jenis alih kode dan menjelaskan fungsi-fungsi alih kode. Jenis-jenis dan fungsi-fungsi alih kode yang digunakan insruktur dapat dilihat pada bagian analisis berikut.

Terdapat beberapa jenis alih kode yang mucul dalam penelitian alih kode menurut para ahli. Menurut Suwito (1983) terdapat 2 jenis alih kode yaitu alih kode interen dan eksteren; dan menurut Wardhaugh (1986) terdapat juga 2 jenis alih kode yaitu alih kode metaforis dan situasional.

Berdasarkan hasil penelitian, jenis alih kode eksteren lebih banyak ditemukan dari pada alih kode interen serta jenis alih kode situasional lebih banyak ditemukan dari pada alih kode metaforis. Berikut ini akan dijelaskan tentang jenis-jenis dan fungsi AK tersebut.

\section{Jenis Alih Kode \\ a. Alih Kode Eksteren}

Wardhaugh (1986) menyatakan bahwa alih kode eksteren yaitu alih kode yang terjadi antar bahasa yang ada dalam lingkungan pemakai bahasa itu dengan bahasa asing. Melia, dkk (2012) dalam penelitian mereka juga menemukan alih kode dalam situasi percakapan orang Minang di Bandarlampung. Terkait dengan penelitian ini alih kode eksteren juga ditemukan dalam proses belajar mengajar bahasa Inggris.

Dalam penelitian ini alih kode eksteren yang terjadi yaitu pengalihan kode dari bahasa Inggris (BIng) ke bahasa Indonesia (BI), dari bahasa Inggris (BIng) ke bahasa Melayu Manado (BMM), dan dari bahasa Melayu Manado (BMM) ke bahasa Inggris (BIng)

\section{Instruktur I}

1) You are the first student. Tau apa artinya?

AK di atas termasuk jenis AK eksteren karena pada awalnya instruktur mengatakan pada muridnya bahwa dia adalah muid pertama yang ada di kelas menggunakan BIng seperti pada tuturan "you are the first student" yang kemudian instruktur melakukan alih kode ke dalam BI untuk menanyakan jika mnuridnya mengerti apa yang instruktur katakan seperti pada contoh berikut "tau apa artinya?".

2) First student siswa pertama

AK di atas termasuk jenis AK eksteren. AK sebelumnya menunjukkan instruktur mengatakan kepada muridnya bahwa dia adalah murid pertama dengan menggunakan BIng seperti pada tuturan instruktur berikut "first student" yang kemudian dilakukan alih kode dalam BI seperti pada contoh berikut "siswa pertama".

\section{Instruktur 2}

1) Page sixteen. Sixteen itu brapa?

AK di atas termasuk jenis AK eksteren. Awalnya instruktur menyapa muridmuridnya dan menanyakan apakah murid-muridnya masih mengingat pelajaran kemarin dalam BIng kemudian melakukan alih kode dalam BMM saat menanyakan bahasa Inggris dari angka enam belas seperti contoh berikut "Page sixteen. Sixteen itu brapa?".

2) Listen, point and repeat. Is your ball on the toys box? Is your ball under the table? Is your ball next to the door? Ok. Toys box itu artinya kotak permainan seperti ini

AK di atas termasuk jenis AK eksteren. Awalnya instruktur memberi petunjuk kepada murid apa yang harus dilakukan dan menanyakan beberapa pertanyaan dalam BIng seperti berikut "listen, point and repeat. Is your ball on the toys box? Is your ball under the table? Is your ball next to the door?". Instruktur kemudian melakukan alih kode ke BI saat menjelaskan arti dari toys box seperti pada tuturan berikut "toys box itu artinya kotak permainan seperti ini". 


\section{b. Alih Kode Interen}

Berikut ini pembahasan mengenai alih kode interen yang dilakukan instruktur saat mengajar. Alih kode interen menurut Suwito (1983) merupakan jenis alih kode yang berlangsung antar bahasa yang digunakan dalam suatu negara yang dikuasai oleh individu atau yang digunakan oleh pengguna bahasa itu sendiri. Alih kode yang terjadi dalam penelitian ini yaitu alih kode dari bahasa Indonesia (BI) ke bahasa Melayu Manado (BMM) dan dari bahasa Melayu Manado (BMM) ke bahasa Indonesia (BI).

Alih kode interen tidak hanya ditemukan dalam situasi formal seperti pada proses belajar mengajar bahasa asing, tetapi juga ditemukan pada situasi informal seperti pada tuturan sehari-hari dalam suatu kelompok masyarakat pengguna bahasa. Sama seperti penelitian yang dilakukan oleh Melia, dkk (2012:77). Penelitian mereka menunjukkan, alih kode intern oleh perpindahan topik, orang ketiga, beralihnya suasana, menunjukkan bahasa pertamanya, berbicara dengan orang sekampung, dan saat membicarakan orang lain. Dikaitkan dengan alih kode interen, dalam penelitian ini alih kode interen juga ditemukan dalam proses belajar mengajar walaupun tidak sebanyak alih kode eksteren. Berdasarkan penjelasan di atas dapat dilihat bahwa alih kode banyak dilakukan pada situasi apapun.

\section{Instruktur 1}

1) Besok hari libur jadi nda ada les. Lesnya nanti minggu depan

AK di atas termasuk jenis AK interen karena pada awalnya instruktur berbicara dalam BMM seperti pada tuturan instruktur "besok hari libur jadi nda ada les" kemudian mengalihkannya ke dalam BI seperti pada tuturan instruktur "lesnya nanti minggu depan".

\section{Instruktur 4}

1) I4 : So, let me check your homework

S1 : Salah sto no

I4 : Ah namanya blajar

S1 : Kita nentau ba baca

I4 : So itu ja ba baca bae-bae toh?

AK di atas termasuk jenis AK interen. AK terjadi dalam BI ke BMM. Instruktur awalnya menggunakan BI saat menjelaskan kepada muridnya jangan takut salah karena mereka masih belajar seperti pada tuturan berikut "Ah namanya blajar". AK dilakukan saat murid merespon bahwa dia tidak begitu tahu membaca dalam BIng yang kemudian instruktur memberi respon dengan melakukan AK dalam BMM seperti pada tuturan berikut "So itu ja ba baca bae-bae toh?".

2) Kyapa salah bawa buku dang? Buku apa yang dibawa?

AK di atas termasuk jenis AK interen. Instruktur awalnya menggunkan BMM saat menanyakan kenapa murid tersebut salah membawa buku seperti pada tuturan berikut "Kyapa salah bawa buku dang?". Instruktur melakukan AK dalam BI saat menanyakan buku apa yang dibawa oleh murid tersebut seperti pada tuturan berikut " $\underline{B u k u \text { apa yang }}$ dibawa?".

Dalam penelitian ini, AK interen jarang digunakan jika dilihat dari banyaknya jumlah instruktur yang menggunakannya. Penelitian ini juga di dukung oleh penelitian Sumakul (2013) yang juga mendapatkan 9 kali penggunaan AK eskteren. Yang ditemukan dalam penelitian ini berupa AK dari BI ke BMM dan BMM ke BI. Hasil ini juga sama dengan penelitian yang dilakukan oleh Sumakul (2013) yang mendapatkan AK dari BMM ke BI dan BI ke BMM. 


\section{c. Alih Kode Metaforis}

Berikut ini pembahasan mengenai alih kode metaforis yang dilakukan instruktur saat mengajar. Menurut Wardhaugh (1986) alih kode metaforis yaitu alih kode yang terjadi jika ada pergantian topik pembicaraan. Dalam penelitian ini alih kode yang terjadi mengalami pergantian topik pembicaraan baik yang disebabkan oleh instruktur maupun murid.

AK metaforis tidak hanya ditemukan dalam pembelajaran bahasa Asing tetapi juga ditemukan pada situasi yang lain. Namun dalam penelitian ini, AK metaforis lebih sedikit ditemukan dibandingkan dengan AK situasional.

\section{Instruktur 1}

1) I1 : Hallo Katlea

S1 : Hallo ma'am

I1 : How are you?

S1 : I'm fine thank you

I1 : Do you bring your book? Kid's box and the note book

Ss1 :Yes

I1 : You are the first student. Tau apa artinya? First student siswa pertama

Dilihat dari keseluruhan percakapan, percakapan di atas termasuk dalam AK metaforis yaitu terjadi pergantian topik dalam percakapan. Awalnya instruktur menanyakan jika murid tersebut membawa buku cetak dan buku catatan dan kemudian mengganti topik pembicaraan dengan mengatakan bahwa murid tersebut merupakan murid pertama yang datang.

\section{d. Alih Kode Situasional}

Berikut ini pembahasan mengenai alih kode situasional yang dilakukan instruktur saat mengajar. Menurut Wardhaugh (1986) alih kode situasional yaitu alih kode yang terjadi tanpa adanya pergantian topik pembicaraan. Dalam penelitian ini, AK situasional lebih banyak ditemukan daripada AK metaforis.

\section{Instruktur 1}

1) I1 : Do you have brother or sister?

$\mathrm{S} 1 \quad: N o$

I1 : No? Only you in your family? Cuma anak sendiri?

S1 : Ada adiku. Adik kandung

I1 : Adik kandung? What is your brother or sister? Adik laki-laki ato perempuan?

S1 : Emm sister

I1 : What's your sister's name? Namanya?

S1 : My sister is queen

I1 : My sister name is queen. How old is she? Umurnya berapa?

$\mathrm{S} 1 \quad$ : My sister is old is 11 months

I1 : My sister is 11 months. 11months? 11 bulan?

S1 : Iya

I1 : Is she beautiful? Yes or no? Dia cantik nda?

S1 :Yes

I1 :Yes, she is. Are you beautiful Katlea?

S1 :Yes

I1 :Yes, I am 
Dilihat dari keseluruhan percakapan di atas, percakapan tersebut merupakan jenis AK situasional karena selama proses belajar tersebut tidak terjadi perubahan topik pembicaraan. Proses belajar mengajar yang berlangsung yaitu interaksi instruktur dan murid dalam bentuk latihan percakapan dimana instruktur menanyakan tentang adik dari murid tersebut. Hal ini dapat dilihat dari pertanyaan-pertanyaan instruktur seperti "namanya?, umurnya berapa?, dia cantik nda?".

1) I1 :Do you know what day is tomorrow? Besok hari apa?

S1 : Saturday

I1 : Tomorrow is holiday. Besok hari libur jadi nda ada les. Lesnya nanti $\underline{\text { minggu depan }}$

Dilihat dari keseluruhan percakapan, AK ini juga termasuk jenis AK situasional karena dalam percakapan di atas tidak terjadi pergantian topik pembicaraan. Pembicaraan hanya menyangkut infromasi dari instruktur bahwa besok adalah hari libur dan tidak ada kursus.

\section{Fungsi Alih Kode}

Berikut ini pembahasan mengenai fungsi-fungsi alih kode berdasarkan hasil penelitian. Menurut Margana (2012) ada banyak fungsi alih kode dalam proses komunikasi di kelas yang dikategorikan dalam beberapa kategori yaitu fungsi utama alih kode untuk pembelajaran materi, pengelolaan kelas dan pemarkah wacana. Selain itu ada beberapa fungsi alih kode dalam pembelajaran materi yaitu fungsi klasifikasi, reiterasi, eksplanasi, eksplorasi, elaborasi, pengecekan pemahaman, penekanan terhadap unsur-unsur kebahasaan tertentu, membuat interferensi, mengembangkan kosakata, membahas tugas peserta didik, memberi feedback dan sebagai refleksi.

Dillihat dari fungsinya dalam pengelolaan kelas, alih kode berfungsi untuk menarik perhatian murid, memberikan arahan, menandai pergantian topik, meminta bantuan murid, mengatasi ketegangan, menjaga kedisiplinan peserta didik, memberi motivasi kepada peserta didik, memberi apresiasi terhadap peserta didik, memarahi peserta didik dan memelihara hubungan interpersonal.

Dalam penelitian ini ditemukan beberapa fungsi alih kode dalam proses belajar mengajar bahasa Inggris yaitu fungsi klarifikasi atau konfirmasi, reiterasi atau pengulangan, eksplorasi, eksplanasi, penugasan, pemarkah wacana, pengecekan pemahaman dan memberi peringatan, namun ada beberapa fungsi alih kode yang tidak ditemukan berdasarkan konsep Margana (2012) yaitu fungsi elaborasi, penekanan terhadap unsur-unsur kebahasaan tertentu, membuat interferensi, mengembangkan kosakata, membahas tugas peserta didik, memberi feedback, rekfleksi, menarik perhatian murid, memberi arahan, menandai pergantian topik, meminta bantuan murid, mengatasi ketegangan, menjaga kedisiplinan murid, memberi motivasi, memberi apresiasi, memarahi peserta didik dan memelihara hubungan interpersonal. Berdasarkan banyaknya fungsifungsi alih kode, dapat dikatakan alih kode memiliki peran penting dalam proses belajar mengajar.

Alih kode juga terjadi karena baik instruktur maupun murid memiliki kemampuan menggunakan dua bahasa yaitu bahasa Indonesia dan bahasa Inggris. Kemampuan menggunakan dua bahasa tersebut disebut bilingualisme. Orang yang memiliki kemampuan menggunakan dua bahasa disebut bilingual. Bilingualisme tidak dapat dipisahkan dengan alih kode. Orang yang memiliki kemampuan menggunakan dua bahasa tersebut menggunakan alih kode. Brown (2007) menjelaskan kebanyakan bilingual 
melakukan tindakan alih kode dengan cara memasukkan kata, frase atau yang lebih panjang lagi dari sebuah bahasa ke bahasa lain terutama ketika berkomunikasi dengan sesama bilingual.

Dalam proses belajar mengajar, penggunaan dua bahasa sangat penting untuk terciptanya proses belajar mengajar yang baik. Proses belajar mengajar yang baik berpengaruh pada hasil atau pencapaian murid. Jika hanya menggunakan satu bahasa maka murid akan mengalami kesulitan dalam memahami pelajaran dan hal tersebut berdampak pada hasil yang tidak baik.

Hal ini sesuai dengan yang dinyatakan Basel dan Hidayat (2011) tentang bilingualisme. Menurut mereka, penggunaan dua bahasa bukan semata-mata untuk pencapaian akademik tapi jauh lebih penting untuk integrasi bangsa. Jika hanya menggunakan monolingual berakibat pada murid sulit memahami konsep akademik dan berujung pada prestasi yang buruk dan kepribadian murid yang menurun.

Berikut ini fungsi-fungsi alih kode yang ditemukan dapat dilihat pada tuturan yang diberi huruf tebal berikut:

\section{a. Fungsi Klarifikasi atau Konfirmasi}

Dalam penelitian ini, instruktur melakukan alih kode untuk mengklarifikasi atau mengkonfirmasi perkataan instruktur yang menurut instruktur belum dapat dipahami oleh murid-muridnya. Dengan melakukan klarifikasi atau konfimasi diharapkan murid-murid dapat memahami apa yang disampaikan. Hasil penelitian menunjukkan instruktur melakukan Alih kode untuk mengklarifikasi atau mengkonfirmasi pertanyaan-pertanyaan yang ditanyakannya pada murid-murid tersebut dengan tujuan supaya murid-muridnya memahami apa yang dimaksud atau ditanyakan.

Pernyataan ini didukung oleh Hamzah (2008) dalam yang menyatakan guru beralih ke kode lain untuk mengklarifikasi penjelasannya sendiri yang telah membingungkan siswa. Dia juga menambahkan bahwa dengan klarifikasi tersebut siswa mendapatkan kejelasan tentang apa yang dimaksudkan oleh siswa dan apa yang dilakukannya kemudian.

Alih kode sebagai salah satu cara untuk mengatasi kendala-kendala murid dalam mempelajari bahasa Inggris sangatlah penting. Klarifikasi/konfirmasi digunakan karena keterbatasan murid dalam memahami apa yang dituturkan dalam bahasa Inggris sehingga instruktur perlu melakukan klarifikasi/konfirmasi kembali tuturan yang telah dituturkan instruktur sebelumnya dengan melakukan alih kode. Murid dalam mempelajari bahasa Inggris juga terkendala dengan rasa percaya diri dalam merespon tuturan instruktur. Murid biasanya takut merespon karena takut melakukan kesalahan dalam menjawab maupun dalam pengucapannya. Hal itulah yang membuat kurangnya rasa percaya diri murid. Tanpa adanya alih kode klarifikasi/konfirmasi, murid takut atau malu untuk berkomunikasi. Adanya klarifikasi/konfirmasi dari murid membuat instruktur dapat mengetahui kemampuan muridnya dalam merespon sesuatu, apakah telah memahami pelajaran atau tidak.

Mendukung pernyataan di atas, alih kode dengan fungsi klarifikasi/konfirmasi sangat diperlukan seperti pada hasil wawancara dengan murid yang menyatakan mereka menginginkan penggunaan dua bahasa dalam belajar. Maka, dengan adanya pengalihan kode untuk mengklarifikasi/mengkonfirmasi sesuatu, murid dapat memahami dan dapat merespon apa yang dklarifikasi instruktur.

Alih Kode instruktur yang termasuk dalam fungsi klarifikasi atau konfirmasi sebagai berikut :

\section{Instruktur 3}


1) I3 : Let me choose Stefani. Stefani what's this? It's a chair. Do you know how to write chair? Tau nda bagaimana menulis chair?

Ss : Tau

I3, Ss : It's CHAIR

\section{Instruktur 4}

1) I4 : Belum se terus? Lanjutkan skarang ne. Lanjutannya skarang jo. Yang kemarin yang sebelum ini mana kote yang torang ada skip? Ini sudah kang?

S4 : Blum

I4 : Blum kang? Ini blum lagi?

S4 : Blum

I4 : Ih blum kote kwa kyapa ngana so di seblah disitu dang perasaan kemarin baru sampe sini? Ini?

S4 : Ini sudah

Dilihat dari tuturan-tuturan instruktur di atas dapat dikatakan AK berhasil dilakukan sesuai dengan fungsinya. Setelah instruktur melakukan AK dari BIng ke BI ataupun ke BMM dapat dilihat muridnya dapat memahami pertanyaan yang ditanyakan oleh instruktur melalui jawabannya. AK pada fungsi ini dinyatakan berhasil pada saat murid dapat merespon apa yang disampaikan instruktur.

Berdasarkan data wawancara, ternyata hasil wawancara mendukung data rekaman alih kode yang dilakukan instrukur dalam menanyakan kemnali materi pelajaran atau yang disebut klarifikasi/konfirmasi. Tuturan instruktur ini diperkuat dengan hasil wawancara pada I2 yang menyatakan salah satu alasannya menggunakan AK saat instruktur mengklarifikasi/mengkonfirmasi pelajaran yang yang sedang dipelajari.

\section{b. Fungsi Reiterasi atau Pengulangan}

Reiterasi atau pengulangan digunakan karena dianggap penting. Biasanya sesuatu yang diulang baik bunyi, kata atau kalimat dilakukan untuk menekankan pada sebuah konteks yang sesuai (Keraf, 1996).

Dalam penelitian ini, repetisi dilakukan dengan cara mengulang kata yang sama tapi dalam bahasa yang berbeda. Instruktur biasanya menyatakan sesuatu dalam BIng yang kemudian diulang lagi pernyataan atau pertanyaan tersebut namun dalam BI ataupun BMM yang merupakan bahasa yang dipahami oleh murid. Dengan kata lain, instruktur melakukan alih kode dari BIng ke BI atau ke BMM dengan cara mengulang maksud yang sama dalam bahasa yang berbeda.

Sesuai dengan manfaat alih kode dalam proses belajar mengajar bahasa Inggris untuk mengatasi kendala-kendala murid dalam belajar, alih kode pengulangan sangat penting untuk digunakan karena tidak semua murid dalam kelas mengerti apa yang disampaikan atau yang ditanyakan. Dengan adanya pengulangan seperti dalam penelitian ini pengulangan dari bahasa Inggris ke bahasa Indonesia atau bahasa Melayu Manado, semua murid dapat memahami maksud instruktur dan dapat merespon tuturan instruktur tersebut.

\section{Instruktur 1}

1) First student siswa pertama

\section{Instruktur 3}

1) Now you are going to label these pictures. Jadi kalian semua akan memberi nama gambar-gambar ini 


\section{c. Fungsi Eksplorasi}

Margana (2012) dalam penelitiannya mengatakan bahwa guru bahasa Inggris melakukan AK dari BIng ke BI untuk mengeksplor pengetahuan sebelumnya yang terkait dengan topik materi pelajaran yang akan dipelajari.

Kebanyakan murid merasa malu atau takut dalam membuat kesalahan dalam berkomunikasi saat mempelajari bahasa Inggris. Alih kode eksplorasi sangat penting dilakukan karena dengan adanya fungsi ini, murid dilatih rasa percaya dirinya dengan cara mengeksplor kemampuan berbahasanya. Murid yang awalnya malu atau takut lama kelamaan akan merasa percaya diri dalam berkomunikasi menggunakan bahasa Inggris karena dibantu oleh instruktur. Kenyataan ini ditunjang oleh pernyataan Hanifatul (2009) yang juga menyatakan beberapa kendala yang dialami murid dalam belajar bahasa Inggris yaitu kendala dalam bercakap-cakap dalam bahasa Inggris, kurangnya kosakata yang dimiliki murid, kurangnya rasa percaya diri murid dalam berkomunikasi atau menyatakan pendapat, materi ajar yang tidak sesuai dengan kebutuhan dan lingkungan yang kurang mendukung proses pembelajaran.

Dalam penelitian ini instruktur melakukan fungsi eksplorasi untuk mengeksplor pengetahuan. Tuturan I1 nomor 1 juga dapat dilihat keberhasilan dilakukannya alih kode dalam fungsi ini. Instruktur yang mengeksplor kemampuan murid dalam menjelaskan rencana liburannya dapat dijawab oleh murid tersebut setelah dilakukan alih kode.

Contoh lainnya, pada tuturan I1 nomor 2 dapat dilihat instruktur mengeksplor pengetahuan muridnya tentang keluarganya. Salah satu yang dibahas guna mengeksplor kemampuan seorang murid yaitu dengan menanyakan tentang adik dari murid tersebut. Keberhasilan alih kode dalam fungsi ini dapat dilihat bahwa murid tersebut dapat menjawab semua yang ditanyakan oleh instruktur tersebut.

\section{Instruktur 1}

1) I1 : Where do you want to go tomorrow? Katlea mau kemana besok?

S1 :I'm go to the beach

I1 : I will go to the beach

S1 : Beach

I1 : Beach artinya apa?

S1 : emm pantai

I1 : Pantai. Dengan siapa?

S1 : Mother, father and grandmother

2) I1 : Do you have brother or sister?

$\mathrm{S} 1 \quad:$ No

I1 : No? Only you in your family? Cuma anak sendiri?

S1 : Ada adiku. Adik kandung

I1 : Adik kandung? What is your brother or sister? Adik laki-laki ato perempuan?

S1 : Emm sister

I1 : What's your sister's name? Namanya?

S1 : My sister is Queen

I1 : My sister name is queen. How old is she? Umurnya berapa?

S1 : My sister is old is 11 months

I1 : My sister is 11 months. 11 months? 11 bulan?

S1 : Iya

I1 : Is she beautiful? Yes or no? Dia cantik nda?

S1 :Yes 
I1 : Yes, she is.

\section{d. Fungsi Eksplanasi}

Margana (2012) dalam penelitiannya menyatakan bahwa peristiwa AK dari BIng ke dalam BI digunakan untuk fungsi menjelaskan konsep atau makna bentuk-bentuk bahasa Inggris atau menjelaskan aturan gramatika bahasa Inggris. Dengan melakukan AK tersebut, peserta didik lebih memahami materi yang dibicarakan sehingga mereka dapat menggunakannya dalam memproduksi bentuk-bentuk bahasa Inggris.

Setiap murid dalam mempelajari bahasa Inggris tidak sama. Salah satu yang membuat ketidaksamaan dalam memahami pelajaran yaitu perbedaan kemampuan. Ada murid yang cepat memahami namun ada pula yang lambat memahami. Dengan adanya perbedaan tersebut, maka alih kode merupakan cara yang tepat untuk mengatasinya. Dengan adanya alih kode sebagai fungsi eksplanasi, instruktur tetap dapat menjelaskan materi pembelajaran dengan menggunakan alih kode walaupun kemampuan murid berbeda. Dengan adanya fungsi ini, instruktur dapat menjelaskan materi pembelajaran dengan jelas dan tepat serta mudah dipahami. Rachmawati (2012) menyatakan ada fenomena lain yang membuat murid sulit belajar atau mempelajari bahasa. Fenomenafenomena tersebut yaitu rendahnya kemampuan intelektual, gangguan perasaan/emosi, kurangnya motivasi anak untuk belajar, usia yang terlalu muda, latar belakang sosial yang tidak menunjang, kemampuan mengingat yang rendah, terganggunya alat-alat indera, proses belajar mengajar yang tidak sesuai dan tidak adanya dukungan dari lingkungan belajar.

Dalam penelitian ini, instruktur melakukan AK dari BIng ke BI ataupun BMM untuk menjelaskan aturan gramatika bahasa Inggris. Dapat dilihat pada tuturan I3 nomor 1 instruktur melakukan AK dengan tujuan untuk menjelaskan cara menjawab pertanyaan yang sederhana seperti cara menjawab pertanyaan "how old are you". Penjelasan diberikan oleh instruktur disertai dengan latihan cara menjawab. Setelah itu dapat dilihat keberhasilan dari AK tersebut, murid tersebut dapat memahami penjelasan yang diberikan melalui jawabannya dibawah ini:

\section{Instruktur 3}

1) I3 : How old are you Stefani? This is the answer. Jadi kalo di tanya how old are you jawabannya I am five. Ok? Kalo mam tanya how old are you ini ma'am ya. Ini ma'am yg bilang, ini Stefani. Ok? Ha, jadi how old are you?

S1 : I am five

I3 : That's it.

Berdasarkan data wawancara, ternyata hasil wawancara mendukung data rekaman alih kode yang dilakukan instruktur dalam menjelaskan materi kepada murid. Tuturan instruktur ini diperkuat dengan hasil wawancara dengan I3 yang menyatakan alasannya menggunakan AK saat instruktur menjelaskan materi kepada muridnya yang berupa pattern.

\section{e. Fungsi Penugasan}

Margana (2012) menyatakan bahwa AK dari BIng ke dalam BI atau sebaliknya juga digunakan untuk fungsi pemberian arahan, latihan atau tugas kepada peserta didik. AK dilakukan agar peserta didik mengerti tugas atau kegiatan apa yang dilakukan oleh peserta didik dalam kegiatan proses belajar mengajar. 
Fungsi penugasan sangat penting dilakukan dalam proses belajar mengajar bahasa Inggris. Murid dilatih dan diasah kemampuannya dalam mengerjakan tugas bahasa Inggris melalui penugasan dan dilatih untuk lebih rajin belajar. Alih kode sebagai fungsi penugasan juga sangat penting karena akan sulit untuk instruktur memberi tugas dalam bahasa Inggris dan muridpun akan sulit memahami tugas yang diberikan instruktur jika diberikan hanya dalam bahasa Inggris saja. Namun, dalam memberi penugasan, instruktur menemukan kesulitan. Salah satunya adalah kesulitan dalam mengatur murid karena murid tersebut masih anak-anak. Anak-anak masih masih pada masa bermain sehingga masih sulit untuk mengajak murid pada usia dan tingkatan kelas tersebut untuk diajak belajar dengan serius.

Dalam penelitian ini, instruktur melakukan AK dari BIng ke dalam BI untuk dengan tujuan untuk memberikan latihan kepada murid-muridnya. AK terkait fungsi ini dapat dilihat pada tuturan I3 nomor 1, instruktur memberi tugas kepada murid-muridnya untuk memberi nama gambar-gambar yang ada. Tuturan yang sama sering diulang oleh instruktur untuk selalu mengingatkan tugas yang harus dilakukan yaitu memberi nama gambargambar yang ada.

Contoh lain pada tuturan I3 nomor 2, instruktur dengan tegas memberi arahan kepada murid-muridnya untuk memperhatikan kata-kata yang ada didepan yang akan digunakan untuk memberi nama gambar-gambar yang ada. Pada contoh tuturan I5 dapat dilihat adanya fungsi memberi penugasan. Instruktur menyuruh murid tersebut untuk cepat mengerjakan tugasnya karena murid awalnya menolak.

\section{Instruktur 3}

1) Ok now divide the group. Group Bernard here group Echa here. Come on. You have to label all these things. Ok? Jadi semuanya kasi nama yang ini ya

2) Look! Lihat alphabet!

\section{Instruktur 5}

1) S1 : Kita tidak hafal itu sir.

I5 : Why don't?

S1 : Kita somo ulangan

I5 : Ha?

S1 : Somo ulangan senin depan

I5 : Cepat!

Berdasarkan data wawancara, ternyata hasil wawancara mendukung data rekaman alih kode yang dilakukan instrukur dalam melakukan pengulangan terhadap apa yang telah disampaikan sebelumnya kepada murid. Tuturan instruktur ini diperkuat dengan hasil dengan I5 yang menyatakan salah satu alasan menggunakan AK saat instruktur memberi tugas terkait dengan materi yang diajarkan kepada murid-muridnya.

\section{f. Fungsi Pengecekan Pemahaman}

Margana (2012) terkait dengan fungsi ini menyatakan bahwa peristiwa AK dari BIng ke dalam BI yang dilakukan oleh guru bahasa Inggris digunakan untuk fungsi membahas kembali apakah peserta didik masih mengingat materi yang diajarkan.

Alih kode dengan fungsi pengecekan pemahaman penting dibuat oleh instruktur untuk mengetahui tingkat pemahaman murid mengenai pelajaran yang dipelajari. Setiap murid berbeda tingkat kemampuannya, sehingga kemampuan dalam memahami pelajaranpun berbeda. Tingkat kemampuan menjadi kendala murid dalam mempelajari bahasa Inggris. Hal inipun yang membuat instruktur harus mampu mengatasi kendala yang 
dialami murid tersebut sehingga murid-murid tetap dapat memahami pelajaran walaupun kemampuan mereka berbeda-beda.

Purwanto (1990) menyatakan dapat tidaknya seseorang mempelajari sesuatu dengan berhasil, ditentukan atau dipengaruhi oleh taraf kecerdasannya. Dengan perbedaan taraf kecerdasan atau kemampuan, pengecekan pemahaman diperlukan untuk mengevaluasi keberhasilan proses belajar mengajar.

Dalam penelitian ini, instruktur melakukan AK dari BIng ke dalam BI ataupum BMM untuk mencari tahu apakah murid-muridnya telah memahami apa yang disampaikan ataupun yang ditanyakan. Keberhasilan AK dalam fungsi pengecekan pemahaman dapat dilihat pada jawaban-jawaban muridnya.

Pada keseluruhan contoh tuturan di bawah ini dapat dilihat instruktur mengecek pemahaman muridnya tentang sesuatu yang sementara dipelajari dengan melakukan AK. Keberhasilan AK tersebut dapat dilihat pada jawaban-jawaban murid yang telah memahami maksud dari pertanyaan instruktur setelah melakukan AK.

\section{Instruktur 1}

1) I1 : What's lucu in English? Lucu pe bahasa Inggris apa? S1 : Funny

\section{Instruktur 3}

1) I3 : Do you know how to write chair? Tau nda bagaimana menulis chair?

Ss : Tau

I3, Ss : Ok. It's CHAIR (dieja) it's chair

2) I3 : Good afternoon guys. Good afternoon. Ha, bagaimana cara menjawab good afternoon? Good afternoon ma'am. Good afternoon everyone?

Ss : Good afternoon ma'am

Dilihat dari fungs-fungsi AK di atas, terdapat banyak fungsi yang melatarbelakangi instruktur melakukan AK. Banyaknya fungsi AK yang melatarbelakangi terjadinya AK juga didukung oleh penelitian Margana yang juga menemukan banyak fungsi AK. Dalam penelitiannya, terdapat 12 fungsi AK yang ditemukan pada proses pembelajaran bahasa Inggris di tingkat SMA, sedangkan dalam penelitian ini ditemukan 6 fungsi AK. Enam fungsi AK dalam penelitian ini yaitu fungsi klarifikasi/konfirmasi, reiterasi/pengulangan, eksplanasi, eksplorasi, penugasan dan pengecekan pemahaman

Penelitian ini juga didukung oleh Reyes (2004) yang mengatakan bahwa terdapat 11 fungsi AK dalam pembelajaran bahasa Inggris sebagai bahasa kedua di Spanyol. Ajmal (dalam Margana, 2012) juga menemukan 11 fungsi AK berdasarkan hasil penelitiannya pada kelas bilingual. Hamzah (2008) juga menemukan 4 fungsi AK dalam penelitiannya tentang pengguaan kode bahasa dalam pengajaran bahasa Inggris di SMA. Dia juga menyatakan bahwa guru menggunakan AK untuk mencapai tujuan pedagogikal. Jika dalam penelitian ini, instruktur melakukan AK untuk mencapai beberapa tujuan seperti yang telah dikemukakan di atas, Merritt, dkk (dalam Hamzah, 2008) menemukan bahwa guru sekolah di Kenya melakukan AK antar bahasa untuk memfokuskan perhatian siswa, melakukan klarifikasi dan menekankan materi yang di ajarnya. Camagarajah (dalam Hamzah, 2008) juga menemukan bahwa guru bahasa Inggris di Sri Lanka melakukan AK untuk manajemen kelas dan penyampaian isi pelajaran.

Berdasarkan pada fungsi-fungsi yang telah ditemukan oleh beberapa peneliti di atas dapat dikatakan bahwa instruktur melakukan AK karena adanya tujuan yang ingin dicapai. Dengan adanya fungsi AK, murid dapat memahami apa yang diajarkan. Seperti contoh berikut ini : 
I1 : Where do you want to go tomorrow? Katlea mau kemana besok?

S1 : I'm go to the beach

I1 : I will go to the beach

Dilihat dari percakapan di atas, murid dapat memahami pertanyaan dari instrukturnya saat instruktur tersebut melakukan AK. Setelah isntruktur melakukan AK, murid tersebut langsung dapat menjawab pertanyaan instruktur dengan mengatakan bahwa dia akan pergi ke pantai besok dalam BIng walaupun masih terdapat kesalahan dalam tata bahasa.

I3 : Do you know how to write chair? Tau nda bagaimana menulis chair?

Ss : Tau

I3, Ss : Ok. It's CHAIR

Contoh di atas menunjukkan pentingnya fungsi alih kode dalam pengajaran bahasa asing. Saat instruktur melakukan alih kode murid dapat menjawab pertanyaan yang ditanyakan. Pada contoh di atas saat instruktur melakukan alih kode untuk menanyakan cara menulis kata "chair", murid-murid langsung mengetahui maksud yang disampaikan. Hal ini dapat dilihat pada saat murid-murid tersebut secara bersama-sama dapat mengeja kata "chair".

I3 : How old are you Stefani? This is the answer. Jadi kalo di tanya how old are you jawabannya I am five. Ok? Kalo mam tanya how old are you ini ma'am ya. Ini ma'am yang bilang, ini Stefani. Ok? Ha, jadi how old are you?

S1 : I am five

I3 : That's it.

Contoh lain yang dapat ditunjukkan yaitu pentingnya AK untuk menjelaskan materi yang diberikan agar dapat dipahami murid. Percakapan di atas menunjukkan seorang murid yang tidak memahami bagaimana cara menjawab pertanyaan "how old are you" akhirnya mampu memahami cara menjawab setelah instruktur menjelaskan caranya dengan menggunakan AK dalam BI.

Berdasarkan data wawancara, ternyata hasil wawancara mendukung data rekaman alih kode yang dilakukan instrukur dalam mengecek pemahaman murid. Tuturan instruktur ini diperkuat dengan hasil wawancara dengan I2 yang menyatakan salah satu alasan menggunakan AK saat instruktur ingin mengecek pemahaman murid tentang materi yang dipelajari bersama.

\section{g. Fungsi Peringatan atau Nasehat}

Margana (2012) dalam penelitiannya menyatakan bahwa salah satu fungsi alih kode dalam pembelajaran bahasa Inggris yaitu berfungsi untuk memberi peringatan. Selanjutnya, Margana menjelaskan bahwa fungsi dilakukan oleh guru karena murid yang datang terlambat, membuat kegaduhan, membuat ulah agar diperhatikan, tidak mau mengerjakan tugas yang diberikan, membuat kesalahan dan sebagainya.

Fungsi peringatan/nasehat sangat penting dilakukan untuk membuat murid lebih rajin lagi belajar. Murid diberi peringatan supaya mereka mengetahui tugas dan tanggung jawab mereka untuk belajar. Nasehat/peringatan juga sangat penting untuk memotivasi murid dalam belajar. Murid tidak termotivasi dan akan malas belajar jika tidak diberikan peringatan/nasehat. Salah satu yang menjadi kendala murid dalam belajar bahasa Inggris adalah motivasi belajar. Kurangnya motivasi belajar akan berdampak buruk bagi kemampuan murid. Kurangnya motivasi bisa saja motivasi dari diri sendiri ataupun motivasi dari orang tua, guru dna lingkungan tempat murid tersebut tinggal, seperti yang 
dikemukakan Rachmawati (2012) mengenai fenomena yang muncul terkait dengan kendala seorang murid belajar yang salah satunya yaitu motivasi.

Dalam penelitian ini, peringatan dibuat oleh instruktur untuk memberi nasehat kepada murid-muridnya untuk lebih teliti dan lebih rajin lagi dalam belajar. Instruktur juga menginginkan supaya murid-muridnya rajin mengerjakan PR yang diberikan.

Dilihat pada tuturan di bawah, tuturan I4 no 1 instruktur membuat fungsi peringatan untuk memperingatkan murid-muridnya untuk segera menyelesaikan PR yang setelah itu akan dikumpulkan. Setelah PR dikumpulkan mereka akan mengikuti ujian akhir. Berbeda dengan contoh no 2, instruktur membuat fungsi peringatan untuk menasehati muridmuridnya untuk lebih teliti dan lebih rajin lagi belajar membaca buku bahasa Inggris baik di tempat kursus maupun di rumah.

\section{Instruktur 4}

1) Because after that you have your exam or your test. Setelah ma'am so lia ngana pe PR samua baru mo tes

2) S1 : Ma'am kita nentau ba baca

I4 : So itu ja ba baca bae-bae

Berdasarkan data wawancara, ternyata hasil wawancara mendukung data rekaman alih kode yang dilakukan instrukur dalam hal memberi nasehat kepada murid. Tuturan instruktur ini diperkuat dengan hasil wawancara yang menyatakan salah satu alasan menggunakan alih kode saat memberi nasehat kepada muridnya.

Jika dilihat dari penggunaan fungsi-fungsi alih kode yang sudah dibahas di atas, jelas dapat dilihat bahwa alih kode sering digunakan baik oleh instuktur maupun murid. Sering digunakannya alih kode oleh instruktur karena adanya situasi murid tidak bisa diajarkan hanya dengan menggunakan bahasa Inggris. Murid tidak bisa diajarkan hanya dengan menggunakan bahasa Inggris karena adanya kendala-kendala. Kendala-kendala tersebut seperti adanya kesulitan dalam menguasai kosakata bahasa Inggris, kurangnya rasa percaya diri siswa sehingga mereka sulit berkomunikasi menggunakan bahasa Inggris dan lingkungan yang kurang mendukung siswa tersebut belajar. Hanifatul (2009) menyatakan bahwa alih kode sering dilakukan dalam proses belajar mengajar karena adanya kendalakendala yang dialami siswa seperti kendala dalam bercakap-cakap dalam bahasa Inggris, minimnya perbendaharaan kata, kurang rasa percaya diri, kurang motivasi, metode mengajar yang kurang tepat, materi ajar yang tidak sesuai dan lingkungan yang kurang mendukung. Fungsi AK bermanfaat untuk mengatasi hal kesulitan-kesulitan murid. Hal ini dapat dilihat dari proses belajar mengajar yang ditunjukan murid dalam respon mereka.

Sesuai dengan wawancara pada S1-S4, umumnya mereka mengatakan lebih mengerti jika instruktur menggunakan BIng dan BI dalam mengajar di kelas dan mereka lebih menginginkan jika di dalam kelas menggunakan dua bahasa bukan hanya BIng. Hal ini dapat dilihat pada jawaban murid berikut.

1) $\mathrm{P} \quad$ : Kalo $\mathrm{S} 1$ lebe mangarti pake bahasa Inggris ato bahasa Indonesia?

S1 : Dua-dua

$\mathrm{P} \quad$ : Paling suka? pake bahasa Inggris ato Indonesia?

S1 : Dua-dua

2) $\mathrm{P} \quad$ : Lebe suka belajar pake bahasa Inggris trus ato bahasa Indonesia?

S2 : Campur-campur

$\mathrm{P} \quad$ : Yang S2 ja mangarti?

S2 : Dua-dua 
3) $\quad \mathrm{P}$ : Coba mem tanya S3 dang. S3 lebe suka pake bahasa Inggris ato bahasa Indonesia?

S3 : Dua-dua

Pada siswa yang mempunyai kemampuan yang tinggi dengan prestasi yang sangat baik, siswa tersebut lebih suka menggunakan bahasa yang digunakan oleh instruktur dalam hal ini BIng. Hal ini dapat dilihat pada jawaban seorang murid yang lebih suka menggunakan BIng dibandingkan BI dalam proses belajar mengajar dalam kelas. Keinginan murid tersebut menggunakan BIng seperti berikut.

$\mathrm{P} \quad$ : Waktu I1 menagajar pake bahasa Inggris mengajar S4 mengerti ato bagaimana?

S4 : Kalo mengerti tapi kalo ada yang belum mengerti langsung ditanya

$\mathrm{P} \quad$ : Tapi kebanyakan mengerti?

S4 : Ia

P : Ok. Good. Kalo S4 lebe suka bahasa Inggris atau bahasa Indonesia? Ato kebanyakan yang mana sukanya?

S4 : Lebih sukanya sih bahasa Inggris.

Pada murid dengan kemampuan yang lebih baik, bila instruktur memberi pertanyaan dalam BI, siswa juga menjawab menggunakan BIng. Bila instruktur menggunakan BI, siswa juga menjawab menggunakan BI. Hal ini dapat dilihat pada jawaban murid berikut.

1) $\mathrm{P} \quad$ : Kalo I4 tanya pake bahasa Inggris $\mathrm{S} 1$ ja jawab pake bahasa apa?

S1 : Bahasa Inggris

$\mathrm{P} \quad$ : Kalo I4 tanya pake bahasa Indonesia S1 ja jawab pake bahasa apa?

S1 : Bahasa Indonesia

2) $\mathrm{P} \quad$ : Kalo I5 tanya pake bahasa Inggris $\mathrm{S} 2$ mo jawab pake bahasa apa?

JR : Bahasa Inggris no.

$\mathrm{P} \quad$ : Kalo I5 tanya pake bahsa Indonesia S2 mo jawab pake bahasa apa?

S2 : Bahasa Indonesia

3) $\mathrm{P} \quad$ : Waktu I1 ba tanya-tanya pake bahasa Inggris ja jawab?

S4 : Ia

$\mathrm{P} \quad$ : Pake bahasa Inggris juga? Ato?

S4 : Kadang-kadang pake bahasa Inggris sama bahasa Indonesia

$\mathrm{P} \quad$ : Kalo I1 tanya pake bahasa Inggris, S4 jawab pake bahasa Inggris ato bahasa Indonesia?

S4 : Bahasa Inggris

$\mathrm{P} \quad$ : Kalo I1 tanya pake bahasa Indonesia, S4 jawab pake bahasa Inggris ato bahasa Indonesia?

S4 : Bahasa Indonesia

Murid yang kemampuannya lebih rendah, lebih dominan menggunakan BI dalam kelas. Hal ini dapat dilihat pada saat instruktur jika menanyakan dalam BIng, murid tersebut lebih memilih menggunakan BI dalam memberi respon atau dalam menjawab pertanyaan instruktur. Inilah yang membuat instruktur lebih banyak menggunakan BIng dan BI karena adanya perbedaan kemampuan siswa. Pemilihan BI oleh murid tersebut dapat dilihat pada jawaban murid tersebut pada wawancara berikut.

$\mathrm{P} \quad$ : Kalo I5 tanya pake bahasa Inggris S3 mo jawab pake bahasa apa?

S3 : Bahasa Indonesia

$\mathrm{P} \quad$ : Kalo I5 tanya pake bahasa Indonesia S3 mo jawab pake bahasa apa?

S3 : Bahasa Indonesia 
P : Bahasa Indonesia. Lebe suka S3 pake bahasa Inggris trus ato bahasa Indonesia?

S3 : Bahasa Indonesia.

Hal ini sesuai dengan pernyataan Hanifatul (2009) yang mengatakan adanya kendalakendala yang dialami siswa seperti kurangnya perbendaharaan kata, kurang rasa percaya diri, kurangnya motivasi, metode mengajar yang kurang tepat, materi ajar yang tidak sesuai dan lingkungan yang kurang mendukung.

\section{KESIMPULAN}

\section{Jenis Alih Kode}

Instruktur lebih banyak melakukan alih kode eksteren (pengalihan kode dari bahasa Asing (Bahasa Inggris) ke bahasa Indonesia (BI) dan bahasa Melayu Manado (BMM)) dari pada menggunakan alih kode interen (pengalihan kode dari bahasa Indonesia (BI) ke bahasa Melayu Manado (BMM) ataupun sebaliknya) ketika menjelaskan materi pembelajaran kepada murid-murid dan ketika mereka melihat murid-murid tersebut belum memahami apa yang mereka ajarkan atau sampaikan. Alih kode situasional (alih kode yang terjadi tanpa adanya pergantian topik pembicaraan) lebih banyak ditemukan dari pada alih kode metaforis (alih kode yang terjadi karena adanya pergantian topik pembicaraan). Semua jenis alih kode yang ada dalam konsep Wardhaugh dan Suwito ditemukan dalam penelitian ini.

\section{Fungsi Alih Kode}

Dari segi fungsi, fungsi alih kode yang ditemukan dalam penelitian ini yaitu fungsi klarifikasi atau konfirmasi, reiterasi atau pengulangan, eksplorasi, eksplanasi, penugasan, pengecekan pemahaman, dan peringatan atau nasehat. Fungsi reiterasi atau pengulangan lebih banyak ditemukan dari pada fungsi lainnya.

\section{DAFTAR PUSTAKA}

Brown, H. 2007. Principles of language Learning and Teaching. New Jersey: Prentice Hall.

Basel, H dan Hidayat, R. 2011. Sukses Bilingual. Pengantar Implementasi dan Evaluasi Untuk Sekolah dan Pihak Lain yang Membutuhkan. Jakarta: CV NEC Press.

Bogdan, Robert C., and Steven J. Taylor. 1992. Introduction to Qualitative Research Methotds: A Phenomenological Approach in the Social Sciences.

Chaer, A., dan Agustina, L. 2010. Sosiolinguistik: Perkenalan Awal (Ed revisi). Jakarta: Rineka Cipta.

Criper, C., and Widdowson, H.G. 1975. Sosiolinguistics and Language Teaching. Dalam Allen dan Corder (Ed). Reading for Applied Linguistics.

Cameron, L. 2001. Teaching Languages to Young Learners. Cambridge: Cambridge University Press.

Fishman. 1972. The Sociology of Language. Rawly Massachusett: Newbury House.

Hamzah. 2008. Penggunaan Alih Kode Bahasa oleh Guru dalam Pengajaran Bahasa Inggris di Sekolah Menengah Atas. Jurnal Bahasa dan Pembelajaran Bahasa Vol 2 Ed 3 pp 9-26. 
Hanifatul, H. 2009. Alih Kode dan Campur Kode dalam Pembelajaran Emglish Conversation Pada Siswa Kelas X Program ICT SMA Muhammadiyah 1 Karanganyar. Program Studi Pendidikan Bahasa Inggris Program Pasca Sarjana Universitas Sebelas Maret Surakarta.

Harley, B. 1996. Introduction: Vocabulary Learning and Teaching in a Second Language. The Canadian Modern Language Review 53 (1), 3-11

Hudson, Richard A. 1996. Sociolinguistics. Second Edition. Cambridge.

Holmes, Janet. 1992. An Introduction to Sociolinguistics. London: Longman.

Indrastuti,N.S.K. 1997. Alih Kode dan Campur Kode dalam Siaran Radio: Analisis Sosiolinguistik. Humaniora V.

Keraf, G. 1996. Diksi dan Gaya Bahasa. Gramedia Pustaka Utama: Jakarta.

Macnamara. 1967. The Bilingual's Linguistics Performance: A Psychological Overview. Journal of Social Issues, 23 59-77.

Miles, M.B., and Huberman, A.M. 1984. Qualitative Data Analysis. London: Sage Publishers.

Margana. 2012. Alih Kode dalam Pengajaran Bahasa Inggris di SMA di Daerah Istimewa Yogyakarta. Disetrtasi Sekolah Pascasarjana Universitas Gadjah Mada.

Martinet, A. 1987. Ilmu Bahasa: Pengantar (Terjemahan Rahayu Hidayat). Yogyakarta: Kanisius.

Matondang, E. M. 2005. Menumbuhkan Minat Belajar Bahasa Inggris Anak Usia Dini Melalui Music and Movement (Gerak dan Lagu). Jurnal Pendidikan Penabur No.05/ Th.IV / Desember 2005.

Melia, S.,Tarmini, W., Nazaruddin, K. 2012. Alih Kode dan Campur dalam Percakapan Bahasa Indonesia Masyarakat Minang di Bandarlampung dan Implikasinya pada Pembelajaran Bahasa Indonesia di SMA. Jurnal Kata (Bahasa, Sastra, dan Pembelajarannya) Volume 1 Nomor 2 Agustus 2012.

Purwanto. 1990. Psikologi Pendidikan. Bandung: PT Remaja Rosdakarya.

Reyes, I. 2004. Function of Codes-Switching in Schoolchildren's Conversation. Bilingual Research Journal, 28 (1), 77-98.

Rachmawati, A. 2012. Kesulitan Belajar Siswa. Hasil Observasi ke Sekolah. Semarang: IKIP PGRI Semarang.

Suryabrata, S. 2008. Psikologi Pendidikan. Jakarta: PT RajaGrafindo Persada.

Suwito. 1985. Sosiolinguistik: Pengantar Awal. Surakarta: Henary Offset.

Sugiyono. 2010. Metode Penelitian Kuantitatif, Kualitatif dan R\&D. Bandung: Alfabeta Bandung.

Wardhaugh. 1986. An Introduction to Sociolinguistics. Oxford: Basil Blackwell Ltd.

Weinreich, U. 1968. Language in Contact: Findings and Problem. The Hague: Mouton. 